\title{
Combining Abilities of Five Japanese Plum Cultivars for Resistance to Xanthomonas Stem Canker
}

\author{
B.L. Topp ${ }^{1}$ and W.B. Sherman \\ Department of Fruit Crops, University of Florida, Gainesville, FL 32611 \\ D.A. Huber \\ Department of Forestry, University of Florida, Gainesville, FL 32611
}

\section{S.B. Linda \\ Institute of Food and Agricultural Science, University of Florida, Gainesville, FL 32611}

Additional index words. Prunus salicina, Xanthomonas campestris pv. pruni, bacterial spot, fruit breeding, diallel, disease resistance

\begin{abstract}
Analysis of a five-parent diallel in a greenhouse estimated general and specific combining ability (GCA and SCA) effects for resistance of Japanese plum (Prunus salicina Lindl. and hybrids) to Xanthomonas campestris pv. pruni (Smith) Dye stem canker, as measured by length of inoculated cankers, canker appearance rating, and canker expansion rate. 'Friar' and 'Gulfruby' were the most susceptible parents. 'Burbank', 'Wilson', and' Wade' had similar GCA values for length of inoculated cankers, but' Wade' was the superior parent in transmitting canker resistance, as measured by canker appearance rating. SCA was not important in determining the performance of a cross. Canker appearance rating was the best measure of resistance in the greenhouse tests and provided a greater separation of GCA estimates and lower coefficient of variation.
\end{abstract}

Stem cankers on Japanese plum caused by Xanthomonas cause limb breakage or death and also provide a source of overwintering inoculum for spring infection (Feliciano and Daines, 1970; Moffett, 1973). Inheritance of Xanthomonas stem canker resistance in plum has not been extensively documented. Popenoe (1959) found no consistent relationship between stem canker susceptibility and degree of leaf and fruit infection. Resistant Japanese-type plum cultivars had a spreading habit, and he suggested that susceptibility to stem cankers and erect growth habit were derived from $P$. simonii Carr. Norton (1967) noted that resistance to stem cankers in plum seemed to be the result of one major, recessive gene with possible modifying factors. Topp et al. (1991) used clonal variance estimates and calculated a moderately high, broad-sense heritability for Xanthomonas stem canker resistance. Accurately estimating variance components and associated genetic parameters requires large populations and involves many assumptions

Received for publication 6 July 1992 Accepted for publication 10 Dec. 1992. Florida Agricultural Experiment Station Journal Series no. R-02504. We gratefully acknowledge the technical assistance of Dougal M. Russell, who performed the cross-pollinations. The cost of publishing this paper was defrayed in part by the payment of page charges. Under postal regulations, this paper therefore must be hereby marked advertisement solely to indicate this fact.

'Present address: Queensland Dept. of Primary Industries, Granite Belt Horticultural Research Station, P.O. Box 501, Stanthorpe, Queensland 4380, Australia. about the selection of parents and the population from which they were derived (Cockerham, 1963).

Combining abilities are based on first-order statistics (means or sums) and thus provide more robust estimates of inheritance than studies involving variance estimation (Gilbert, 1973; Simmonds, 1979). Diallel mating designs produce full-sib families for estimating parental combining abilities and have been used to provide information on inheritance of disease resistance in fruit trees (Quamme et al., 1990). If a fixed-effects model is used, no genetic assumptions about the population or mating system are required. Combining abilities, therefore, offer several advantages in applied breeding and genetic studies. The purpose of this study was to estimate the general and specific combining ability (GCA and SCA) of five Japanese plum cultivars for resistance to Xanthomonas stem canker.

'Burbank', 'Friar', 'Gulfruby', 'Wade', and 'Wilson' Japanese plums were hybridized at Stanthorpe, Queensland, Australia, to produce nine of the 10 full-sib families for a half diallel. 'Wilson' is pollen sterile and was used only as a seed parent. 'Gulfruby' flowers $\approx 5$ weeks before the other cultivars at Stanthorpe and was used exclusively as a pollen parent. Seeds were stratified, germinated, and planted in $500-\mathrm{ml}$ pots in a greenhouse in Gainesville, Fla., in 1990. The resulting 249 seedlings were arranged in a randomized complete-block design with three replications. There were five to 79 seedlings per family (Table 1 ).

Trees (12 months old) were tested for resistance to Xanthomonas stem canker in June 1991. Actively growing shoots were inoculated with $2.5 \times 10^{8}$ colony-forming units $/ \mathrm{ml}$ of $X$. campestris pv. pruni at three sites in the top $15 \mathrm{~cm}$ using a $0.45-\mathrm{mm}$ (26-gauge) needle and syringe. Measurements of the three inoculations per tree were averaged before analysis. Canker length (CANKA) was measured 28 days after inoculation. The difference in canker length at 14 and 28 days was analyzed as the canker expansion rate (DIFF) in millimeters per day. Canker appearance (CDA) was rated at 28 days using a 1 (clean) to 5 (dirty) scale. Classes 1, 2, and 3 were considered resistant and classes 4 and 5 susceptible.

Estimates of combining ability were obtained by two methods:

A) Means for the missing cross ('Wilson' $x$ 'Friar') were imputed from arithmetic averages of the other crosses, and the five-parent diallel was analyzed using Griffing's method 4, model 1 (Griffing, 1956). Computation was performed using the GRIFFING SAS macro (Linda, 1993). Harmonic means were used for the average number of trees because of the unbalanced design (Hallauer and Miranda Fo, 1981).

B) The incomplete diallel was analyzed as a fixed-effects model corresponding to Griffing's (1956) method 4, model 1 using ordinary least squares with a sum to zero reparameterization to obtain unbiased GCA and SCA estimates (Huber et al., 1992).

Crosses differed in mean CANKA, CDA, and DIFF (Table 1). There were no block effects, a result indicating that the greenhouse environment was uniform in its influence on canker development. 'Friar' $x$ 'Gulfruby' was the most susceptible cross and 'Burbank' $x$ 'Wade' the most resistant when the overall results for all three traits were considered (Table 2). Three variables were used to mea-

Table 1. Observed mean squares from randomized complete block analyses of variance for inoculated canker length (CANKA) (in millimeters), canker appearance (CDA) on a 1-5 scale, and canker expansion rate (DIFF) (in millimeters per day). Mean and $c v$ are presented for CANKA, CDA, and DIFF.

\begin{tabular}{lrccc}
\hline & & \multicolumn{3}{c}{ Mean square } \\
\cline { 2 - 4 } Source & df & CANKA & CDA & DIFF \\
\hline Cross & 8 & $454.334^{* *}$ & $7.567^{* *}$ & $1.199^{* *}$ \\
Block & 2 & $122.265^{\mathrm{Ns}}$ & $1.577^{\mathrm{Ns}}$ & $0.225^{\mathrm{Ns}}$ \\
Cross $\times$ block & 16 & $73.056^{\mathrm{Ns}}$ & $1.749^{\mathrm{Ns}}$ & $0.228^{\mathrm{Ns}}$ \\
Error & 222 & 58.064 & 1.125 & 0.157 \\
Mean & & 15.558 & 4.305 & 0.533 \\
cv $(\%)$ & & 49.0 & 24.6 & 74.3 \\
\hline
\end{tabular}


sure resistance because of the difficulty in describing the many forms of resistance that can occur with a single variable and the change in family ranking that may occur depending on how resistance is measured. Inoculated canker length after 6 weeks has been shown to be (Topp et al., 1991); DIFF is a linear function of two such estimates and likely would be of similar repeatability.

The favorable environment that existed in the greenhouse for canker development, coupled with the high concentration of initial inoculum, may have resulted in watersoaking or canker development in even the most resistant trees. DIFF between 14 and 28 days was used to avoid this possible complication. The rationale was that, even though the most resistant trees in this population might initially develop canker symptoms, a decrease in the rate of canker development would be a component of resistance (Parlevliet, 1979). The ranking of families for CANKA and DIFF were similar, but greater separation of classes was possible using DIFF, as indicated by more significant differences among crosses (Table 2 ). The coefficient of variation for CDA $(24.6 \%)$ was smaller than for CANKA $(49.0 \%)$ and DIFF $(74.3 \%)$, a result indicating that CDA had comparatively less residual error variation.

Differences among the diallel crosses were moderately to highly repeatable in the field

partitioned into fixed effects due to GCA and SCA (Table 3). GCA measures the average performance of a parent in hybrid combination with all other parents in the diallel (Sprague and Tatum, 1942). The highly significant GCA (Table 3 ) indicates that statistically additive features of the parents were important in explaining the differences among crosses. The two methods used to estimate GCA gave similar results (Table 4) for all traits. Method B using least squares provided unbiased estimates for the reparameterized model because data imputation was not necessary. Less similar results would have been expected from a population in which SCA effects were more significant. Negative GCA values are desirable because they indicate lower CANKA, CDA, or DIFF. 'Friar' and 'Gulfruby' were the most potent parents for transmitting susceptibility to cankers. 'Burbank', 'Wade', and 'Wilson' produced offspring with significantly lower CANKA than 'Friar', but were not significantly different from each other in CANKA transmitted to their offspring (Table 4).

SCA measures the deviation of a particular cross from the expected value based on GCA estimates alone (Sprague and Tatum, 1942). SCA was not significant, a result indicating that statistically nonadditive effects were not important in explaining the differences among cross mean values (Table 5). Quamme et al. (1990) reported that SCA effects for bacterial

Table 2. Cross means for inoculated canker length (CANKA) (in millimeters), canker appearance (CDA) on a 1-5 scale, and canker expansion rate (DIFF) (in millimeters per day).

\begin{tabular}{lcccc}
\hline \hline Cross & $\begin{array}{c}\text { Trees } \\
(\text { no. })\end{array}$ & $\begin{array}{c}\text { CANKA }^{2} \\
(\mathrm{~mm})\end{array}$ & $\begin{array}{c}\text { CDA } \\
(1-5)\end{array}$ & $\begin{array}{c}\text { DIFF } \\
\left(\mathrm{mm}^{-1} \cdot \mathrm{day}^{-1}\right)\end{array}$ \\
\hline Wilson x Burbank & 13 & $12.4 \mathrm{~b}$ & $3.9 \mathrm{a}-\mathrm{c}$ & $0.36 \mathrm{c}$ \\
Wilson x Wade & 14 & $14.5 \mathrm{~b}$ & $3.7 \mathrm{bc}$ & $0.43 \mathrm{bc}$ \\
Wilson x Gulfruby & 5 & $13.7 \mathrm{~b}$ & $4.0 \mathrm{a}-\mathrm{c}$ & $0.39 \mathrm{c}$ \\
Burbank x Friar & 23 & $16.5 \mathrm{ab}$ & $4.7 \mathrm{a}$ & $0.56 \mathrm{a}-\mathrm{c}$ \\
Burbank x Wade & 21 & $11.1 \mathrm{~b}$ & $3.3 \mathrm{c}$ & $0.33 \mathrm{c}$ \\
Burbank x Gulfruby & 79 & $12.5 \mathrm{~b}$ & $4.5 \mathrm{ab}$ & $0.38 \mathrm{c}$ \\
Friar x Wade & 9 & $16.7 \mathrm{ab}$ & $3.7 \mathrm{bc}$ & $0.74 \mathrm{ab}$ \\
Friar x Gulfruby & 63 & $21.8 \mathrm{a}$ & $4.8 \mathrm{a}$ & $0.85 \mathrm{a}$ \\
Wade x Gultruby & 22 & $14.4 \mathrm{~b}$ & $3.8 \mathrm{bc}$ & $0.46 \mathrm{bc}$ \\
\hline
\end{tabular}

${ }^{{ }^{2}}$ Mean separation within columns by Duncan's multiple range test at $P \leq 0.05$.

Table 3. Mean squares from combining ability analyses, based on Griffing's (1956) method 4, model 1 for inoculated canker length (CANKA) (in millimeters), canker appearance (CDA) on a 1-5 scale, and canker expansion rate (DIFF) (in millimeters per day).

\begin{tabular}{lrccc}
\hline \hline & & \multicolumn{3}{c}{ Mean squares } \\
\cline { 3 - 5 } Source & $\mathrm{df}^{2}$ & CANKA & CDA & DIFF \\
\hline General combining ability & 4 & $16.813^{* *}$ & $0.431^{\text {** }}$ & $0.0597^{* *}$ \\
Specific combining ability & 5 & $2.940^{\text {Ns }}$ & $0.076^{\text {Ns }}$ & $0.0063^{\text {Ns }}$ \\
Error & 222 & 4.147 & 0.080 & 0.0112 \\
\hline
\end{tabular}

${ }^{2}$ Analysis using imputed data for 'Wilson' $x$ 'Friar' cross.

ws,"*Nonsignificant at $P \leq 0.05$ or significant at $P \leq 0.01$, respectively. fire blight resistance in pear, as measured by stem blight length, were also nonsignificant.

The cross mean for' Wilson' $x$ 'Wade' for CANKA was higher (Table 2) than would have been predicted by the GCA values of the parents (Table 4). This result led to a relatively high positive, though nonsignificant, SCA value for CANKA, a result indicating some nonadditive deviation from the parental GCA values. This event may be a result of the small number (14) of seedlings representing the family. One aberrant seedling in a small family can bias the family mean seriously. Larger families are beneficial because they reduce sampling error and avoid the complications of stray seedlings that may exist in a family due to errors during seed handling or pollination.

GCA parental ranking changed according to which trait was used to measure resistance. CDA measurement of resistance indicated that 'Wade' was superior to the other parents, transmitting on average a rating of 0.666 (on a 1 to 5 scale) below the mean. CANKA measurement of resistance classed 'Burbank', 'Wade', and 'Wilson' in the same category (Table 4). Although trees with clean CDA (1 to 3) generally also had small cankers, there were exceptions. These exceptions seemed to occur more frequently in the greenhouse than in similar field experiments (data not shown), probably because of the rapid stem growth in the greenhouse at the time of inoculation, an event that sometimes resulted in long stem scars (rather than cankers), even for low CDA. For this reason, CDA was considered a more useful measure of resistance in the greenhouse. An index that combined both variables would be a useful selection criterion.

All data were analyzed using Griffing's (1956) fixed-effects model 1 because parents were chosen deliberately from the Queensland Dept. of Primary Industries' (QDPI) Japanese plum breeding program and selected to represent a range of susceptibilities to stem cankers. The main objective was estimating GCA and SCA effects. These estimates are specific for the combination of parents tested. For example, using parents with susceptibility similar to that of 'Friar' to estimate 'Gulfruby' GCA would result in a higher GCA because the estimates are expressed as deviations from the diallel mean. Tree fruit breeders often do not have the resources to include many parents in a diallel, but still want to obtain GCA fixedeffects constants that will be indicative of future performance for the diallel parents. A compromise is to select genetically broadbased material that will represent future popu-

Table 4. Estimates of general combining ability effects obtained by analysis of variance (method A) and ordinary least squares (method B) for inoculated canker length (CANKA) (in millimeters), canker appearance (CDA) on a 1-5 scale, and canker expansion rate (DIFF) (in millimeters per day).

\begin{tabular}{|c|c|c|c|c|c|c|}
\hline \multirow[b]{2}{*}{ Parent } & \multicolumn{3}{|c|}{ Method $\mathrm{A}^{2}$} & \multicolumn{3}{|c|}{ Method B } \\
\hline & $\begin{array}{c}\text { CANKA } \\
(\mathrm{mm})\end{array}$ & $\begin{array}{l}\text { CDA } \\
(1-5)\end{array}$ & $\begin{array}{c}\text { DIFF } \\
\left(\mathrm{mm} \cdot \mathrm{day}^{-1}\right)\end{array}$ & $\begin{array}{c}\text { CANKA } \\
(\mathrm{mm})\end{array}$ & $\begin{array}{l}\text { CDA } \\
(1-5)\end{array}$ & $\begin{array}{c}\text { DIFF } \\
\left(\mathrm{mm} \cdot \text { day }^{-1}\right)\end{array}$ \\
\hline Burbank & $-2.425 \mathrm{c}$ & $0.068 \mathrm{ab}$ & $-0.1310 \mathrm{~b}$ & $-2.867 c$ & $0.017 \mathrm{ab}$ & $-0.1483 b$ \\
\hline Friar & $3.683 \mathrm{a}$ & $0.369 \mathrm{a}$ & $0.2290 \mathrm{a}$ & $4.227 \mathrm{a}$ & $0.431 \mathrm{a}$ & $0.2577 \mathrm{a}$ \\
\hline Gulfruby & $0.857 \mathrm{ab}$ & $0.284 a b$ & $0.0180 \mathrm{~b}$ & $0.400 \mathrm{~b}$ & 0.268 ab & $-0.0089 \mathrm{~b}$ \\
\hline Wade & $-1.047 \mathrm{bc}$ & $-0.576 \mathrm{c}$ & $-0.0196 \mathrm{~b}$ & $-1.483 b c$ & $-0.666 \mathrm{c}$ & $-0.0326 \mathrm{~b}$ \\
\hline Wilson & -1.068 bc & $-0.146 \mathrm{bc}$ & $0.0964 \mathrm{~b}$ & $-0.277 b c$ & $-0.050 \mathrm{~b}$ & $-0.0679 b$ \\
\hline
\end{tabular}

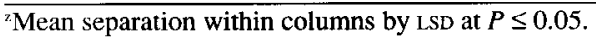


Table 5. Estimates of specific combining ability for each cross obtained by analysis of variance (method A) and ordinary least squares (method B) for inoculated canker length (CANKA) (in millimeters), canker appearance (CDA) on a 1-5 scale, and canker expansion rate (DIFF) (in millimeters per day).

\begin{tabular}{|c|c|c|c|c|c|c|}
\hline \multirow[b]{2}{*}{ Cross } & \multicolumn{3}{|c|}{ Method A } & \multicolumn{3}{|c|}{ Method B } \\
\hline & $\begin{array}{c}\text { CANKA } \\
(\mathrm{mm})\end{array}$ & $\begin{array}{l}\mathrm{CDA} \\
(1-5)\end{array}$ & $\begin{array}{c}\text { DIFF } \\
\left(\mathrm{mm} \cdot \mathrm{day}^{-1}\right)\end{array}$ & $\begin{array}{c}\text { CANKA } \\
(\mathrm{mm})\end{array}$ & $\begin{array}{l}\text { CDA } \\
(1-5)\end{array}$ & $\begin{array}{c}\text { DIFF } \\
\left(\mathrm{mm} \cdot \text { day }^{-1}\right)\end{array}$ \\
\hline Wilson x Burbank & 0.969 & -0.052 & 0.0805 & 0.432 & -0.156 & 0.0591 \\
\hline Wilson $x$ Wade & 1.680 & 0.383 & 0.0423 & 1.098 & 0.294 & 0.0212 \\
\hline Wilson $x$ Gulfruby & -1.015 & -0.191 & -0.0398 & -1.530 & -0.138 & -0.0803 \\
\hline Burbank $x$ Friar & 0.275 & 0.249 & -0.0430 & -0.227 & 0.202 & -0.0697 \\
\hline Burbank $x$ Wade & -0.361 & -0.260 & -0.0268 & 0.126 & -0.154 & -0.0108 \\
\hline Burbank $x$ Gulfruby & -0.883 & 0.063 & -0.0300 & -0.331 & 0.107 & 0.0214 \\
\hline Friar $\times$ Wade & -0.929 & -0.180 & 0.0107 & -1.429 & -0.187 & 0.0001 \\
\hline Friar x Gulfruby & 2.280 & 0.071 & 0.0960 & 1.656 & -0.016 & 0.0695 \\
\hline Wade x Gulfruby & -0.390 & 0.057 & -0.0454 & 0.205 & 0.047 & -0.0106 \\
\hline \multicolumn{7}{|l|}{$\operatorname{LSD}(0.05)$} \\
\hline One common parent & 4.609 & 0.642 & 0.2395 & 4.609 & 0.642 & 0.2395 \\
\hline \multicolumn{7}{|l|}{ LSD (0.05) } \\
\hline No common parents & 3.259 & 0.454 & 0.1694 & 3.259 & 0.454 & 0.1694 \\
\hline
\end{tabular}

lations. Although only five parents were used in this diallel, they encompassed a range of susceptibilities in the QDPI program, which should improve the utility of GCA estimates.

This study has demonstrated that there is genetic variation for resistance to Xanthomonas stem canker in this population of Japanese plums and that 'Wade' is a useful parent in breeding for stem canker resistance as measured by CDA and CANKA. The highly significant GCA effect and nonsignificant SCA effect suggest that mean cross performance may be predicted by the average of the parental phenotypic values.

\section{Literature Cited}

Cockerham, C.C. 1963. Estimation of genetic variances, p. 53-94. In: W.D. Hanson and H.F. Robinson (eds.). Statistical genetics and plant breeding. Natl. Acad. Sci.-Natl. Res. Council, Washington, D.C. Publ. 982.
Feliciano, A. and R.H. Daines. 1970. Factors influencing ingress of Xanthomonas pruni through peach leaf scars and subsequent development of spring cankers. Phytopathology 60:1720-1726.

Gilbert, N.G. 1973. Biometrical interpretation. Clarendon Press, Oxford, U.K.

Griffing, B. 1956. Concept of general and specific combining ability in relation to diallel crossing systems. Austral. J. Biol. Sci. 9:463-493.

Hallauer, A.R. and J.B. Miranda Fo. 1981. Quantitative genetics in maize breeding. Iowa State Univ. Press, Ames.

Huber, D.A., T.L. White, R.C. Littel, and G.R. Hedge. 1992. Ordinary least squares estimation of general and specific combining abilities from half-diallel mating designs. Silvae Genetics 41(4-5):263-272.

Linda, S.B. 1993. GRIFFING: A SAS macro implementing Griffing's analysis of diallel crossing systems. HortScience 28:61.

Moffett, M.L. 1973. Bacterial spot of stone fruit in Queensland. Austral. J. Biol. Sci. 26:171-179.

Norton, J.D. 1967. Resistance to bacterial canker in plum. Proc. Assn. Southern Agr. Workers, 64th Annu. Convention, New Orleans. p. 227-228.

Parlevliet, J.E. 1979. Components of resistance that reduce the rate of epidemic development. Annu. Rev. Phytopathol. 17:203-222.

Popenoe, J. 1959. Relation of heredity to incidence of bacterial spot on plum varieties in Alabama. Proc. Assn. Southern Agr. Workers, 56th Annu. Convention. p. 176-177.

Quamme, H.A., F. Kappel, and J.W. Hall. 1990. Efficacy of early selection for firelight resistance and the analysis of combining ability for fire blight resistance in several pear progenies. Can. J. Plant Sci. 70:905-913.

Simmonds, N.W. 1979. Principles of crop improvement. Wiley, New York.

Sprague, G.F. and L.A. Tatum. 1942. General vs. specific combining ability in single crosses of corn. J. Amer. Soc. Agron. 34:923-932.

Topp, B.L., W.B. Sherman, and R.E. Stall. 1991. Comparison of rating methods for bacterial spot resistance in Japanese-type plum. Fruit Var. J. 45:70-74. 